\title{
Revenue and Tourist Reporting Application for the City of Pekanbaru
}

\author{
Salhazan Nasution* \\ Department of Informatics Engineering \\ Universitas Riau \\ Pekanbaru, Indonesia \\ salhazan@lecturer.unri.ac.id
}

\author{
Ahmad Mulyadi \\ Department of Informatics Engineering \\ Universitas Riau \\ Pekanbaru, Indonesia \\ ahmad.mulyadi1863@student.unri.ac.id
}

\begin{abstract}
Tourism service is a field that aims to introduce and promote marine and other tourism in a certain location especially in marketing field to attract tourists to visit that tourist destination. Culture and Tourism Service of Pekanbaru is one of the technical services which handles government business which is compulsory affairs in culture field and choice affairs in tourism field. The total of tourist visits must be reported to tourism office in each destination. To facilitate the reporting of the total of tourists then, a website and an android-based system are built. The system is developed using the CodeIgniter web framework with PHP and HTML programming language. The application is developed using Android Studio and Java Development Kit. Research result on Progress and recapitulation reports system of the revenue and total Tourists in Pekanbaru City based on web and android which ease to conduct report on total of tourist visits. Usability Testing of this system using the USE Questionnaire and Likert Scale.
\end{abstract}

Keywords - revenue, tourism, reporting, web, android

\section{INTRODUCTION}

A website is an information system that gives easiness for those who want to access it. Advancement of the smartphone with an Android system this time can be utilized for various things. One of which is to support government effort to conduct data collection of income and total tourist visits, especially tourists in Pekanbaru City, Riau [1].

A website consists of web pages that have a domain and contains various information. A domain is a unique name owned by a company or an institution, an address that can be accessed through internet. A homepage is the initial page of a domain. A web page is a page when the user can press the menus and switches to go to the other locations [2].

An Android is a Linux based information system made for smartphone and tablet computers. Android is a platform which can be said as complete in its operations, applications, and development tools, application market of Android and support from the various open-source community in the world. These aspects rapidly support Android development on its device and technology counterparts.[3].
Android Studio is an official Integrated Development Environment (IDE) in the development of Android application based on IntelliJ IDEA. The great development of the IntelliJ code editor, moreover, Android also provides many more features, increasing productivity for building Android applications. [4].

The measurement of usability using questionnaires can process the data related to effectiveness, efficiency, and satisfaction in using a system. According to the International Standard Organization (ISO), USE is one of the questionnaire packages that can be used to measure usability because it covers the three dimensions of usability measures such as efficiency, effectiveness, and satisfaction. USE questionnaire is a questionnaire package consisting of 4 (four) research variables which are usefulness variable, satisfaction variable, ease of learning variable, and ease of use variable [5].

\section{MATERIALS AND METHODS}

\section{A. CodeIgniter}

CodeIgniter is a strong and popular PHP framework. CodeIgniter is useful to developers who need a simple and elegant toolkit in making a web-based application with complete features. The advantages of CodeIgniter is a small framework, supports MVC (Model View Controller), clear documentation, good security level with default protection towards CSRF and XSS attack. There are several advantages of CodeIgniter, such as [6] :

- A simple solution for complex problems. CodeIgniter supports MVC (Model-View-Controller).

- A framework with a small footprint. CodeIgniter version 3 has a downloadable package of $2 \mathrm{MB}$ and includes a user guide. CodeIgniter version 4 it has a $1.2 \mathrm{MB}$ downloadable package plus $6 \mathrm{MB}$ for the user guide.

- Clear documentation.

- Exceptional performance. CodeIgniter has consistently outperformed most of its competitors. 
- Security. High security with built-in protection against CSRF and XSS attacks, as well as in CodeIgniter Version 4 has added context-sensitive escapes and CSP.

- Nearly zero configuration. Configuration of CodeIgniter is done by convention, such as placing the view in the "view" folder and scripts in the "config" folder contains several configurations.

\section{B. Design Pattern MVC (Model View Controller)}

MVC functions to separate data access and business logic from data presentation and also from user interactions. This separation is conducted so that each change in presentation logic or business logic does not give a complicated effect on others. The solution for the separation of MVC is expected to improve flexibility and usability of the application reuse [7].

MVC is the main component in building web application by separating the development of application according to the main components such as data manipulation, user interface, and parts which control the application. There are 3 types of components used to build MCV in an application, such as [8]:

- The Model functions to manipulate data from a database such as an insert, update, delete, and search data. Besides manipulating data from the database, the model can also handle validation from the controller but is not related to the view part.

- The View functions as a recipient and displays data to the user. Usually, it is an HTML template file and this section does not have access to the model part.

- The Controller functions as a regulator of the relationship between the view and part of the model by working to receive requests and data from user input and then run the process as requested in an application.

The MVC principle can be developed through its developers, the programmer handles the controller and the model, then the design handles the view so that it can improve the maintainability and organization of the code. Figure 1 shows the MVC architecture form of the CodeIgniter framework [8].

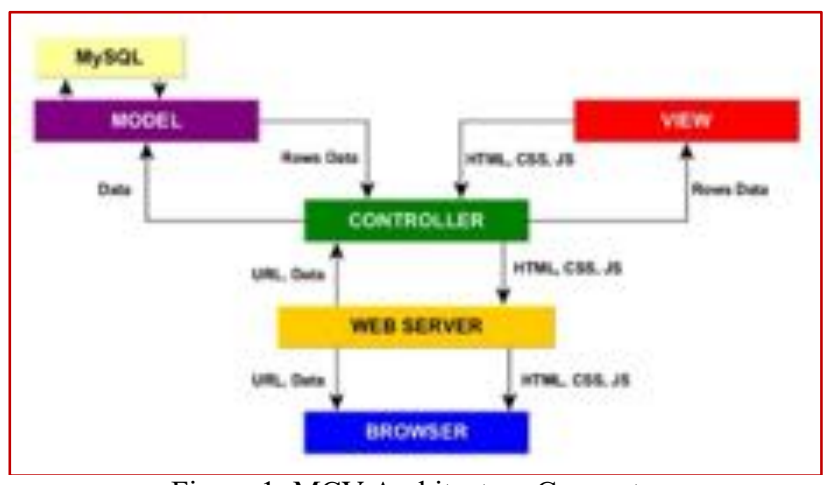

Figure 1: MCV Architecture Concepts

\section{Usability Testing}

Usability testing is a method to measure the efficiency, easiness, and ability in memorizing how to interact without difficulties and mistakes, in other words, this usability testing is an attribute in accessing how easy to use interface website [9].

USE Questionnaire or Usefulness, Satisfaction, and Ease of use Questionnaire are questionnaires that often used to measure the usability of the computer system. Questions in this questionnaire deliver positively that the intended results are biased. Some questionnaires try to avoid the bias source but often occur in other bias sources. The sample is reliability test, which means that the same questionnaires can have different results at different times (examined by measuring the reliability of questionnaire re-test) [10]. The function of that questionnaire is assessed in its validity because there is no guarantee that the questionnaire measures user satisfaction [11].

The measurement of usability using questionnaires can process the data related to effectiveness, efficiency, and satisfaction in using a system [12]. According to the International Standard Organization (ISO), USE is one of the questionnaire packages that can be used to measure usability because it covers three dimensions of usability measures such as efficiency, effectiveness, and satisfaction. USE questionnaire is a questionnaire package consisting of 4 (four) research variables, which are usefulness variable, satisfaction variable, ease of learning variable, and ease of use variable [5].

\section{Likert Scale}

Likert scale is a set of items that can be used together. The important difference between item and aggregate scale can result in many controversies related to "the best" or the analytical approach is accepted. As time goes by, the use of the Likert scale shifts away from respondent's tightness of agreement with statements and what might be seen in frequency or importance [13].

Table 1: Likert Scale Assessment Table

\begin{tabular}{|c|c|}
\hline Answer Scale & Value \\
\hline Strongly Agree (SA) & 5 \\
\hline Agree (A) & 4 \\
\hline Neutral (N) & 3 \\
\hline Disagree (D) & 2 \\
\hline Strongly Disagree (SD) & 1 \\
\hline
\end{tabular}

The percentage value on each score is shown in table 2 .

Table 2: Rating Percentage Table [15]

\begin{tabular}{|c|c|}
\hline Percentage Value & Information \\
\hline $0 \%-20 \%$ & Very Unsatisfying \\
\hline $21 \%-40 \%$ & Not Satisfying \\
\hline $41 \%-60 \%$ & Neutral \\
\hline $61 \%-80 \%$ & Satisfying \\
\hline $81 \%-100 \%$ & Very Satisfying \\
\hline
\end{tabular}

Likert Scale aims to reassure the respondent to answer various questions or statements in the questionnaire. The levels used by the Likert scale have different weights. Likert 
scale often uses levels of Strongly Agree (SA), Agree (A), Neutral (N), Disagree (D), and Strongly Disagree (SD). In obtaining the right value to describe individual attitudes, the process firstly ordinal values on the Likert scale into the form of an interval scale. Likert scale calculations have 5 scores for each answer showed in table 1 [14].

\section{E. Prior Research}

In the research conducted by Rudi Banu Kuncoro in 2012 in the journal entitled "The Making of New Nglepen Dome House Tourist Destination Website." The background problem of this research is that many foreign and domestic visitors are not aware of the existence of the New Nglepen Dome House, while the system used for publication too is information through word of mouth. This became the problem so that it causes a question of how to design an information system to inform the tourists about the existence of Dome New Nglepen Dome House Tourist Destination. Then a system is made called Website Tourism of the New Nglepen Dome House. The making of this website based system uses JQuery, PHP and MySQL so that this research can become reference in website based system making websites [16].

\section{F. Analysis of Software Use of Android Applications}

To run this system, Android software is required which has a minimum standard specification shown in table 3 .

Table 3: Android Software Analysis Table

\begin{tabular}{|c|c|}
\hline Operating System & Android 4.4 KitKat \\
\hline Memory/RAM & $1 \mathrm{~GB}$ \\
\hline ROM & $16 \mathrm{~GB}$ \\
\hline
\end{tabular}

\section{ReSEARCh Methodology}

This research stage contains steps to resolve the problem so that the research objectives can be achieved. Figure 3 shows the research methodology.

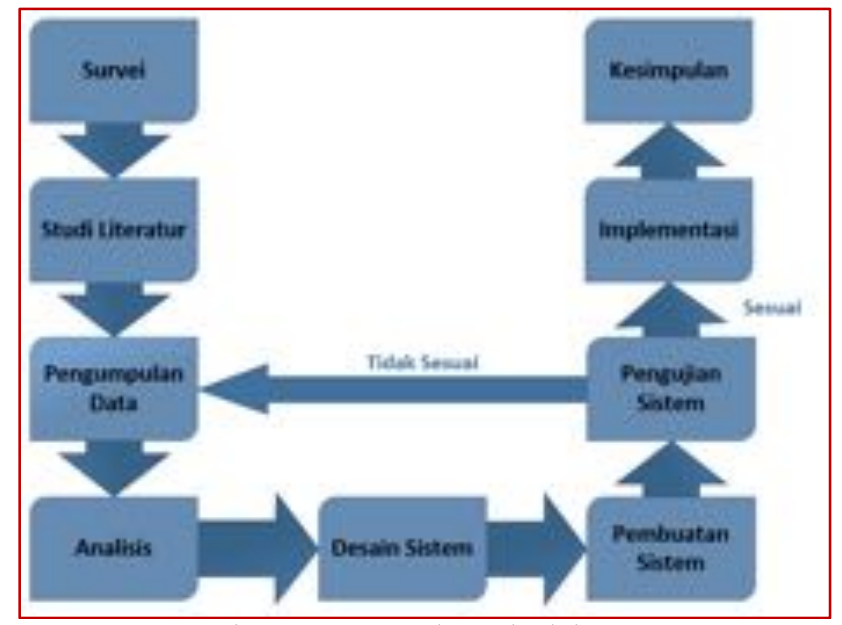

Figure 3: Research Methodology
This system research methodology starts from a survey that is observing and analyzing existing problems in the environment. second, the study of literature on references relating to research and obtaining data for use in solving these problems. third, data collection is done by interview. Fourth, Analysis are activities of distinguishing, elaborating, filtering also observing information. Fifth, system design is conducted by the process of making the initial design or prototype system to be made. Figure 4 displays the stage of research in system design part.

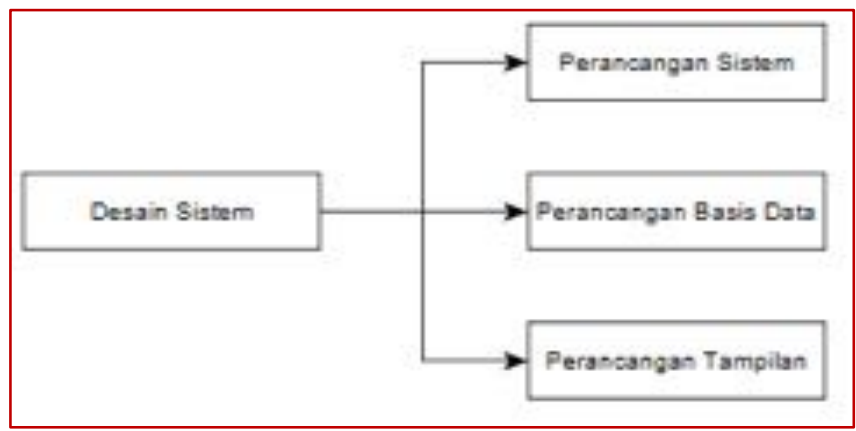

Figure 4: Research Stages of the System Design Section

The next stage in making the system is writing program code. Seventh, testing the system to get the conclusion whether the system is as expected and can be implemented well. Finally, the system implementation is the stage after the system development and testing has been completed and the system is ready to use.

\section{RESUlt AND DisCUSSION}

\section{A. Data Flow Diagram (DFD)}

Data Flow Diagram (DFD) is a model of a system, explains the division of system to a module to ease the analysis starting from context diagram, overview diagram and detailed diagram which is arranged in levels. Data Flow Diagram (DFD) functions to illustrates and documented the complete system or system which still in development stage. Figure 6 shows the diagram level 0 .

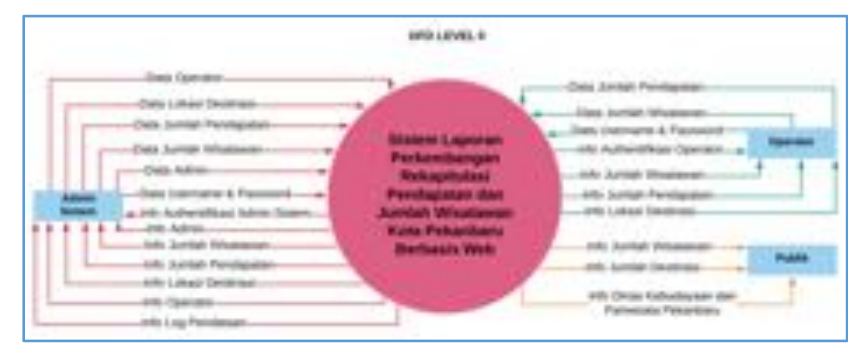

Figure 6: DFD Level 0

\section{B. Flowchart}

Web system flowchart is a flowchart used to describe the workflow of the overall web system. Figure 5 shows the system admin flowchart. 


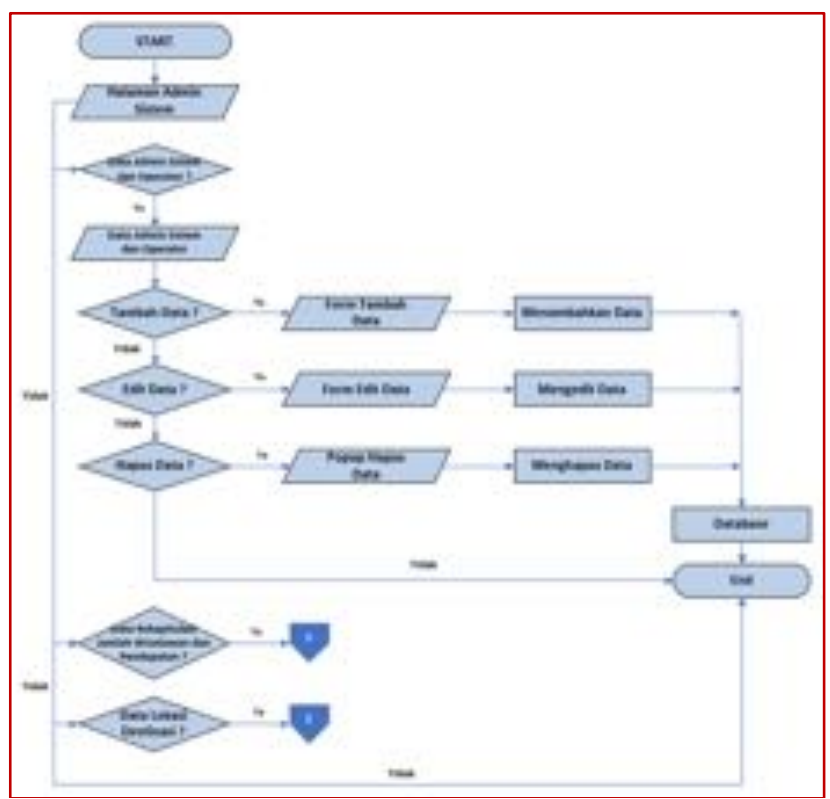

Figure 5: System Admin Flowchart

\section{Website Based System}

Before entering the system, the user must log in first by entering his/her email address and password. Figure 7 shows the login page.

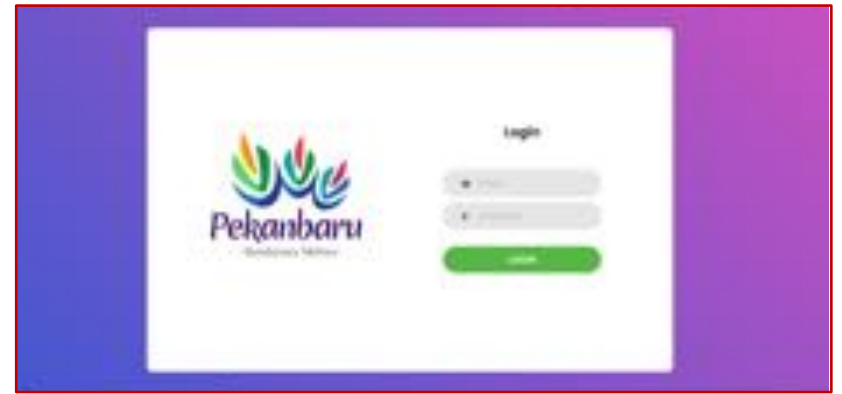

Figure 7: Login Page

After logging in, the website will display the home menu which is the initial display for this system. On display only shows the logo, image, and a few words. Figure 8 shows the home page.

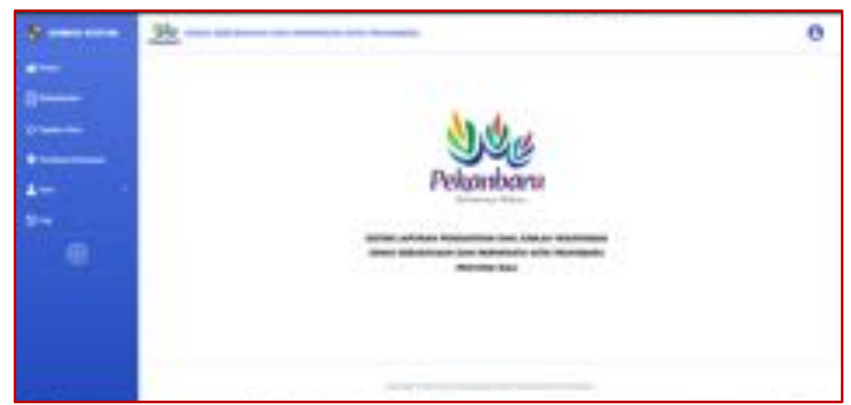

Figure 8: Home page

The Recapitulation menu will display the results of the recapitulation of the number of foreign tourists and domestic tourists in the form of tables. Figure 9 shows the recapitulation page.

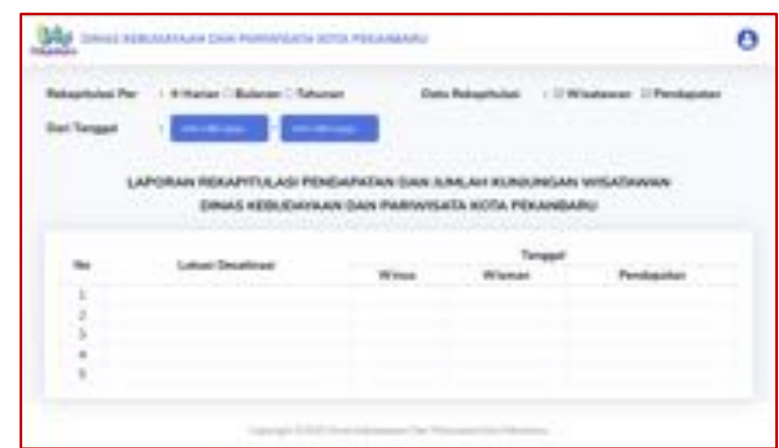

Figure 9: Recapitulation Page

Data update menu functions to edit data stored in the database. Figure 10 shows the data update page.

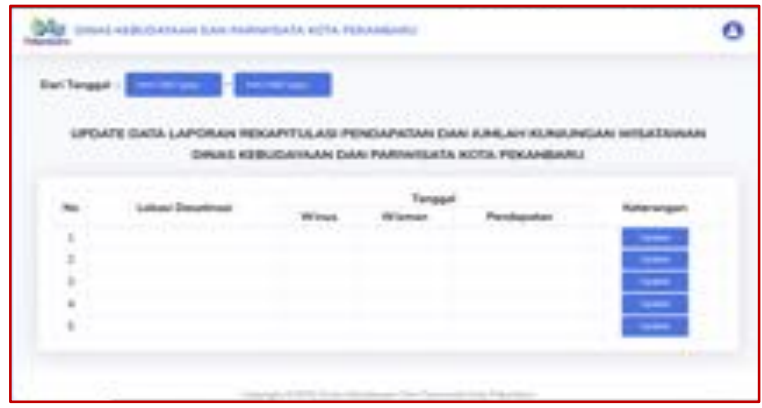

Figure 10: Data Update Page

This Destination Location menu will display the location of tourism destinations and their addresses. Figure 11 shows the destination location page.

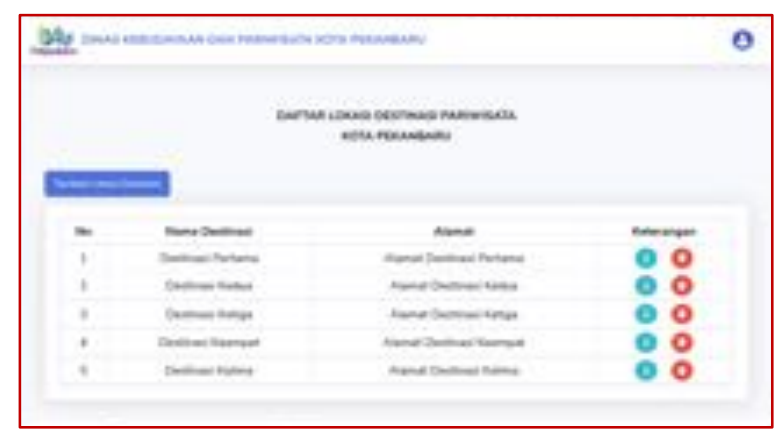

Figure 11: Destination Location Page

The Admin submenu on the User menu will display a list of system admin data. System admins accessing this system can add, edit, and delete other user data. Figure 12 shows the system admin page.

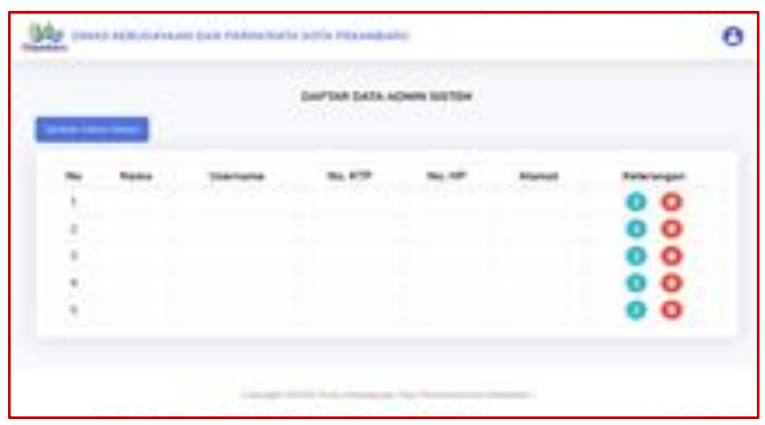

Figure 12: System Admin Page 
The Operator submenu on the User menu will display a list of operator data from each tourist destination location. System admins accessing this system can add, edit, and delete operator data. Figure 13 shows the operator page.

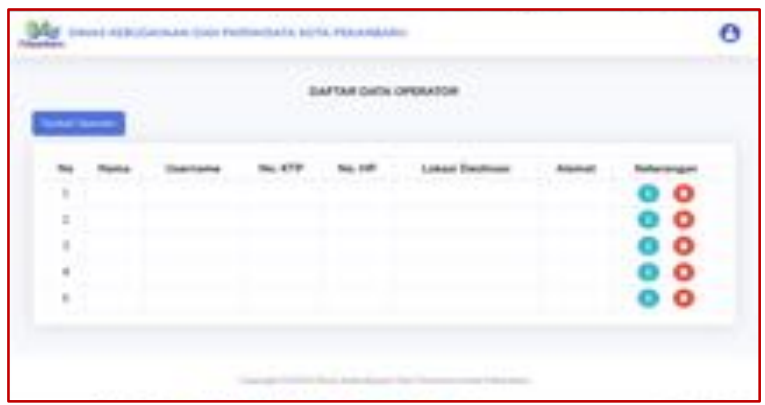

Figure 13: Operator Page

The Data Logging page displays the track record (history). The purpose of the track record here is that it will display every activity carried out by the system admin or operator while using the system related to data collection updates. Figure 14 shows the logging log page.

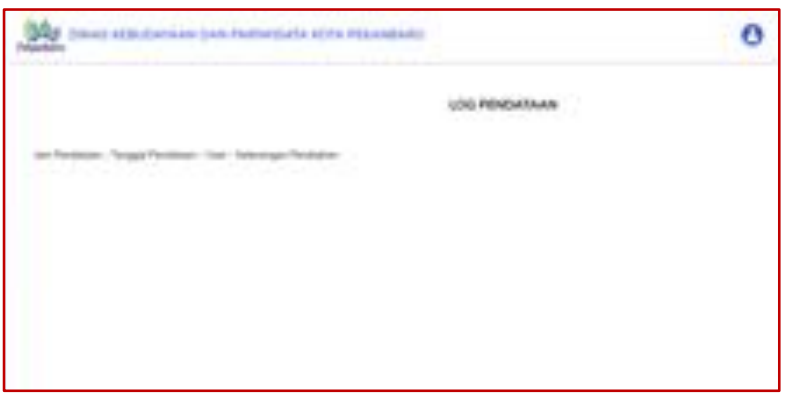

Figure 14: Data Logging Page

\subsection{Android Based Application}

When opening the application, the splash screen lasts for a few seconds to display the welcoming logo from the application Progress and Recapitulation Reports System of the Revenue and Total Tourists in Pekanbaru City. Figure 15 shows the splash screen page.

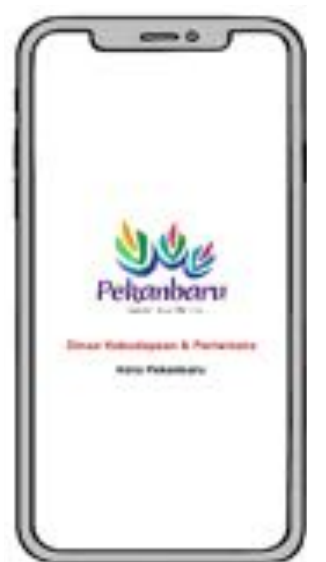

Figure 15: Splash Screen Page

Before entering the application, the user must log in first by entering his/her email address and password. Figure 16 shows the android application login page.

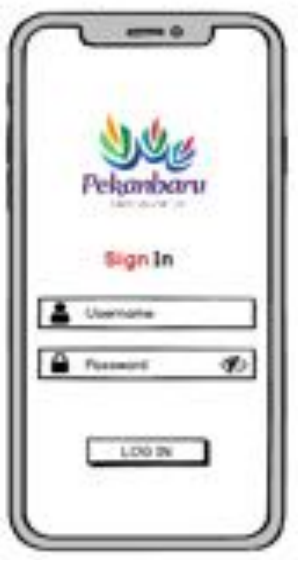

Figure 16: Android Login Page

This data input page functions to input data on the number of tourists and income to Progress and Recapitulation Reports System of the Revenue and Total Tourists in Pekanbaru City. Figure 17 shows the data input page.

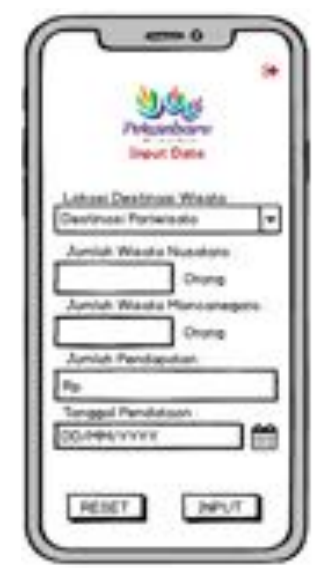

Figure 17: Data Input Page

The page before finishing data input functions to display data that is being inputted at the same time, this display works for operators or system administrators to ensure that the data input is correct. If there is an error in the input data, the operator or system admin can edit the data before the data has been sent to the system by pressing the 'Edit' button. Figure 18 shows before data input are complete.

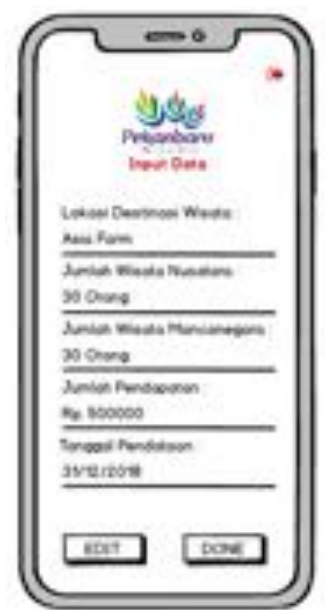

Figure 18: Pages Before Finishing Data Input 
The data edit page functions to conduct data edit of total tourist and income before sent to Culture and Tourism Service of Pekanbaru City Riau Province if the operator or admin of the system conduct errors when inputting data. The editable data is the data that was inputted by operator or system admin in intervals of seconds. Figure 19 shows the data edit page.

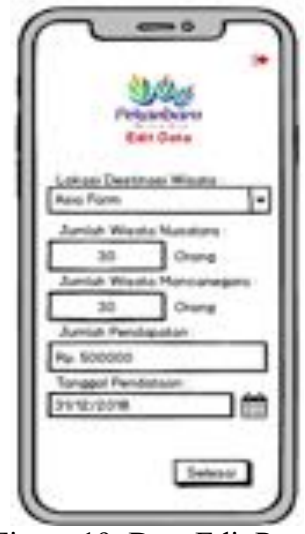

Figure 19: Data Edit Page

The final page is the finished input page. This page only displays the welcoming logo of the application Progress and Recapitulation Reports System of the Revenue and Total Tourists in Pekanbaru City. Figure 20 shows the finished data input.

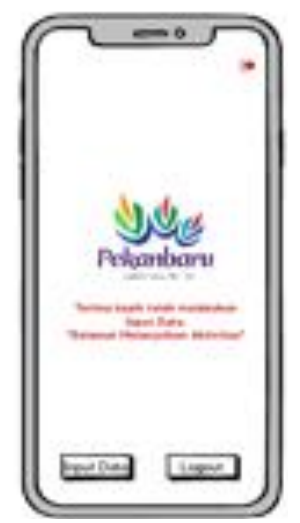

Figure 20: Finished Data Input Page

\section{Likert Scale Calculation}

At this stage, the results of the prototype test questionnaire of the Progress and Recapitulation Reports System of the Revenue and Total Tourists in Pekanbaru City based on Web and Android are known.

The calculation of the total score of the answers given by respondents from the questionnaire results table [17] :

Index Formulation $=\frac{\text { Total Score }}{\mathrm{Y}} \cdot 100 \%$

Average score $=\frac{\text { Total Score }}{\text { Number of Questions }}$

Percentage score $=\frac{\text { Average score }}{\text { Ideal Score Of Total }} \cdot 100 \%$
Information :

$\mathrm{Y}=$ Highest Likert score $\mathrm{x}$ number of respondents

The results of the questionnaire calculation are shown in table 4

Table 4: Prototype Questionnaire Results

\begin{tabular}{|c|c|c|c|c|c|c|c|}
\hline \multirow{2}{*}{ Question } & \multicolumn{5}{|c|}{ Total Answers } & \multirow{2}{*}{$\begin{array}{l}\text { Total } \\
\text { Score }\end{array}$} & \multirow{2}{*}{$\%$} \\
\hline & SD & D & $\mathbf{N}$ & $\mathbf{A}$ & SA & & \\
\hline $\begin{array}{l}\text { The appearance of the } \\
\text { system is already } \\
\text { interesting }\end{array}$ & & & & 9 & 4 & 56 & $86,2 \%$ \\
\hline $\begin{array}{l}\text { The composition of colors } \\
\text { and text used on the } \\
\text { system is appropriate or } \\
\text { not excessive }\end{array}$ & & & & 6 & 7 & 59 & $90,8 \%$ \\
\hline $\begin{array}{l}\text { The system is easy to } \\
\text { understand and learn }\end{array}$ & & & & 4 & 9 & 61 & $93,8 \%$ \\
\hline $\begin{array}{l}\text { The features on each } \\
\text { menu are easy to } \\
\text { understand. }\end{array}$ & & & 1 & 2 & 10 & 61 & $93,8 \%$ \\
\hline $\begin{array}{l}\text { Every text on every } \\
\text { feature is easy to } \\
\text { understand and } \\
\text { understand. }\end{array}$ & & & & 5 & 8 & 60 & $92,3 \%$ \\
\hline $\begin{array}{l}\text { When pressing the bottom } \\
\text { or a feature can display a } \\
\text { popup or page quickly. }\end{array}$ & & & & 9 & 4 & 56 & $86,2 \%$ \\
\hline \multicolumn{6}{|l|}{ Total } & 353 & \\
\hline \multicolumn{6}{|c|}{ Average Score } & 58,8 & $90,5 \%$ \\
\hline
\end{tabular}

Based on the results of the questionnaire from each respondent, a total score of 353 and a percentage score of $90.5 \%$ was obtained using the existing formula. This value can be interpreted referring to table 2, which means the prototype of this system is in a category of "Very Satisfying."

\section{CONCLUSION}

This research results in a system based on web and Android. The prototype of Progress and Recapitulation Reports System of the Revenue and Total Tourists in Pekanbaru City is built to ease the destination operators in the revenue and total tourists report in each tourist destination in Pekanbaru City. The usability testing of this prototype system is conducted by 13 respondents and the result of usability testing questionnaire obtained total score of 353 and score percentage of $90,5 \%$ with category "Very Satisfying”.

\section{REFERENCES}

[1] Sriyati, F. Satria, S. Hartati, and Sudewi, "Pemanfaatan E-Goverment Sebagai Media Promosi di Bidang Pariwisata Ekonomi Kreatif (Studi Kasus : Dinas Pariwisata Kabupaten Pesawaran),”pp. 80-87, 2017.

[2] R. Sovia and J. Febio, "Membangun Aplikasi E-Library Menggunakan HTML, PHP Script, dan MySQL Database," Processor, vol. 6, no. 2, pp. 38-54, 2011.

[3] Z. M. Noer and K. Ngamali, "Aplikasi Perpustakaan SMK Siliwangi AMS Banjarsari Berbasis Android," JUMIKA-Jurnal Manaj. Inform., vol. 4, no. 2, pp. 41-50, 2017.

[4] Android Developers, "Meet Android Studio", https://developer.android.com, 2019.

[5] W. A. Kusuma, V. Noviasari, and G. I. Marthasari, "Analisis Usability dalam User Experience pada Sistem KRS Online UMM menggunakan USE Questionnaire," J. Nas. Tek. Elektro dan Teknol. Inf., vol. 5, no. 4, pp. 294-301, 2016.

[6] EllisLab, "CodeIgniter Rocks," www.codeigniter.com, 2019. . 
[7] S. Baghaskara and Suhendra, "Complaint Handling Ticketing Application Web Based Using Codeigniter Framework (Case Study at PT Indosat Ooredoo Tbk Jakarta)," Int. J. Comput. Sci. Mob. Comput., vol. 7 , no. 12 , pp. $14-28,2018$

[8] W. Istiono, Hijrah, and Sutarya, "Pengembangan Sistem Aplikasi Penilaian dengan Pendekatan MVC dan Menggunakan Bahasa PHP dengan Framework Codeigniter dan Database MYSQL pada Pahoa College Indonesia," J. TICOM, vol. 5, no. 1, pp. 53-59, 2016.

[9] W. Hidayat et al., "Penerapan Metode Usability Testing Pada Evaluasi Situs," 2014.

[10] S. Nasution, A. H. Nasution, and A. L. Hakim, "Pembuatan Plugin Tile-Based Game Pada Unity 3D," IT J. Res. Dev., vol. 4, no. 1, pp. 46-60, Aug. 2019

[11] R. Firmansyah, "Usability Testing Dengan Use Questionnairi Pada Aplikasi Sipolin Provinsi Jawa Barat," vol. 6, no. 1, pp. 1-7, 2018.

[12] S. Nasution and R. A. Frianti, "Sistem Informasi Inventori Obat Berbasis Web di Rumah Sakit Universitas Riau," Semin. Nas. APTIKOM 2019, vol. 0, no. 0, pp. 402-409, Nov. 2019.
[13] S. E. Harpe, "How to analyze Likert and other rating scale data," Sci. Pharm. Teach. Learn. Learn., vol. 7, no. 6, pp. 836-850, 2015.

[14] D. W. Putra, A. P. Nugroho, and E. W. Puspitarini, "Game Edukasi Berbasis Android Sebagai Media Pembelajaran Untuk Anak Usia Dini,” J. Inform. Merdeka Pasuruan, vol. 1, no. 1, pp. 46-58, 2016.

[15] Maryuliana, I. M. I. Subroto, and S. F. C. Haviana, "Sistem Informasi Angket Pengukuran Skala Kebutuhan Materi Pembelajaran Tambahan Sebagai Pendukung Pengambilan Keputusan Di Sekolah Menengah Atas Menggunakan Skala Likert," J. Transistor Elektro dan Inform. (TRANSISTOR EI), vol. 1, no. 2, pp. 1-12, 2016.

[16] R. B. Kuncoro, "Pembuatan Website Tempat Parawisata Rumah Dome New Nglepen," Speed J. - Sentra Penelit. Eng. dan Edukasi, vol. 4, no. 11 , pp. 36-41, 2012.

[17] B. T. Yuridistia, "Sistem Informasi Penjualan Biji Kopi Berbasis Website (Studi Kasus: Selanala Coffee)," Universitas Islam Indonesia, 2018. 